\title{
Seasonal variability of microbial respiration and bacterial and archaeal community composition in the upper twilight zone
}

\author{
M. G. Weinbauer ${ }^{1,2, *}$, J. Liu ${ }^{1,3}$, C. Motegi ${ }^{1,2}$, C. Maier ${ }^{1,2}$, M. L. Pedrotti ${ }^{1,2}$, M. Dai $^{3}$, \\ J. P. Gattuso ${ }^{1,2}$
}

${ }^{1}$ Université Pierre et Marie Curie, UMR 7093, Laboratoire d'Océanographie de Villefranche, 06230 Villefranche-sur-Mer, France ${ }^{2}$ CNRS, UMR 7093, Laboratoire d'Océanographie de Villefranche, 06230 Villefranche-sur-Mer, France

${ }^{3}$ State Key Laboratory of Marine Environmental Science, Xiamen University, 361005 Xiamen, China

ABSTRACT: The mesopelagic ('twilight') zone of the ocean is the sandwich layer between euphotic surface waters and the deep ocean. The physical, chemical, and biological processes in this layer strongly influence the marine carbon cycle, although some surprising knowledge gaps remain, e.g. with respect to microbial communities. We therefore determined biological parameters such as microbial abundances, community respiration, and bacterial and archaeal community composition (as assessed by 16S rRNA gene PCR denaturing gradient gel electrophoresis, DGGE) over a seasonal time scale (at ca. 46 d intervals for 433 d) at a coastal mesopelagic site in the NW Mediterranean Sea (Point C, $300 \mathrm{~m}$ depth) and related them to physicochemical parameters. Some chemical and most biological parameters showed strong variability, thus confirming the emerging view that this water layer is more dynamic than previously thought. Community respiration was likely influenced by seasonal changes as indicated by its indirect relationship with water density. The high detected community respiration rates $(0.23-$ $1.65 \mu \mathrm{mol} \mathrm{O} \mathrm{O}_{2} \mathrm{l}^{-1} \mathrm{~d}^{-1}$ ) confirm that the twilight zone plays a critical role as a hub between surface and deep water. Statistical analyses indicate that water stratification, dissolved organic carbon, and transparent exopolymeric particles were controlling factors of bacterial community composition, whereas the archaeal community was likely controlled by other mechanisms. A sequence analysis of DGGE bands and a literature comparison suggests some specificity of the mesopelagic zone regarding bacterial and archaeal community composition, thus further confirming the peculiarity of this water layer.

KEY WORDS: Mesopelagic · Transparent exopolymeric particles · Carbon cycle · Prokaryote - Virus · Flagellate

Resale or republication not permitted without written consent of the publisher

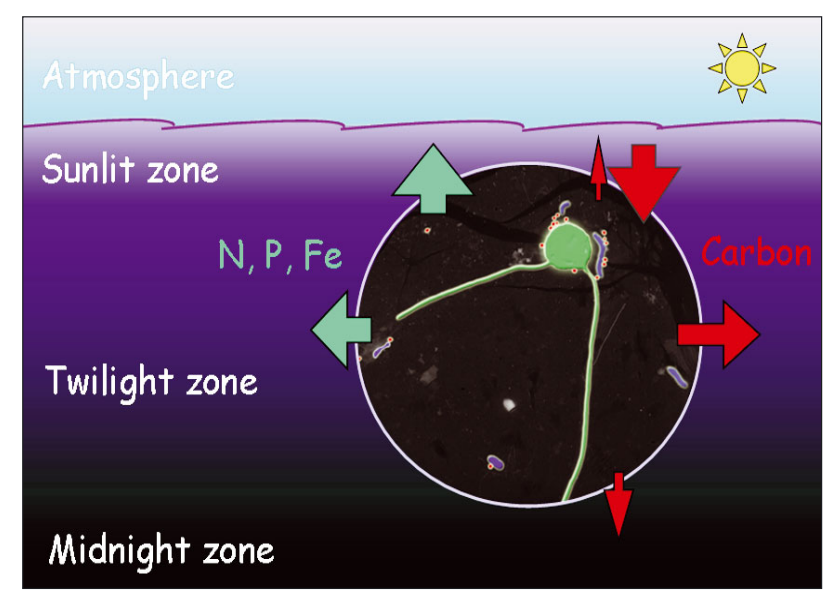

Crucial role of the microbial loop (blue: prokaryotes; red: viruses; green: flagellate) for nutrient regeneration and carbon processing in the twilight zone.

Image credit: Markus Weinbauer

\section{INTRODUCTION}

The mesopelagic zone is usually defined as the layer below the epipelagic zone, i.e. extending from ca. 100-200 m down to ca. $1000 \mathrm{~m}$. Some light penetrates into the mesopelagic layer, but its intensity is not sufficient for net photosynthesis (hence 'twilight zone'). Depth profiles show the presence of an oxygen minimum zone, a rapid decrease of the sinking flux of particulate organic matter, a decrease of dissolved organic matter concentrations, and an increase in concentrations of inorganic nutrients in the mesopelagic layer. This is likely the result of mineral- 
ization of organic matter into $\mathrm{CO}_{2}$ and nutrients (Arístegui et al. 2009, Robinson et al. 2010). Studies on the export and use of organic carbon have given rise to the 'carbon mismatch problem,' i.e. that there is a significant difference between carbon supply and carbon demand in the mesopelagic layer (Burd et al. 2010). The mechanisms of organic matter transformation are currently being unraveled (e.g. Kaiser \& Benner 2012). Recent evaluations suggest that mesopelagic communities are not much less active than epipelagic communities (e.g. Gasol et al. 2009). Integrated respiration in the water column of the dark ocean is comparable to that in the epipelagic zone, and the dark ocean is a site of paramount importance for material cycling in the biosphere (Arístegui et al. 2009). Thus, the mesopelagic zone plays a crucial role as a hub between surface and deep waters by controlling export and recycling processes.

Numerous studies have investigated prokaryotic production in the mesopelagic zone (see review by Arístegui et al. 2009), but studies on community respiration (CR) or prokaryotic respiration (PR) are still limited (Biddanda \& Benner 1997, Arístegui et al. 2005b, Reinthaler et al. 2006). In the global mesopelagic zone, ca. $15 \%$ of CR is associated with zooplankton and the rest is microbial (Bacteria, Archaea, and protists; Arístegui et al. 2005a). Viral lysis of cells and the release of cell content and cell wall debris can also influence microbial respiration rates (Middelboe et al. 1996). Systematic investigations on abundances of predators such as viruses, flagellates, and ciliates in the mesopelagic realm are still comparatively sparse (e.g. Tanaka \& Rassoulzadegan 2002, Fukuda et al. 2007, Magagnini et al. 2007, Parada et al. 2007).

The mesopelagic zone is characterized by specific mixotrophic bacteria and archaea which have the potential for autotrophic $\mathrm{CO}_{2}$ fixation linked to the oxidation of ammonium and sulfur; unrecognized metabolic pathways are likely (Agogué et al. 2008, Swan et al. 2011). The Crenarchaeota, which are hardly detectable in surface water, become numerically as (or almost as) important as Bacteria (e.g. Karner et al. 2001). Also, the microbial (and the viral) community composition shows some specificity for the mesopelagic layer, and the seasonal variability of some microbial parameters can be as high as in the epipelagic zone (e.g. for the Mediterranean zone; Winter et al. 2009a,b, Winter \& Weinbauer 2010)

Overall, recent advances challenge the paradigm of stable microbial food web structure and function and slow organic matter cycling in the dark ocean (Arístegui et al. 2009). The crucial role of the mesopelagic zone as a sandwich layer between surface and deep water becomes even more important when considering potential effects of global change such as warming, acidification, and deoxygenation of the ocean. However, surprising knowledge gaps remain for the mesopelagic realm. For example, few data exist on temporal aspects of mesopelagic water masses such as on the seasonal dynamics of PR and CR. Moreover, studies linking physicochemical parameters, microbial abundances and processes, and microbial diversity are rare. Only few environments have been investigated with respect to microbial parameters, which makes generalizations across systems difficult. Thus, a seasonal study on physicochemical parameters, microbial abundances, CR, and bacterial and archaeal community composition was performed at a coastal mesopelagic site $(300 \mathrm{~m}$ water depth) off the Bay of Villefranche (NW Mediterranean Sea).

\section{MATERIALS AND METHODS}

\section{Study site and sample collection}

The study site was Point $C\left(43^{\circ} 51^{\prime} 00^{\prime \prime} \mathrm{N}, 07^{\circ} 19^{\prime}\right.$ 00" E) off the entrance of the Bay of Villefranche (France, NW Mediterranean Sea). Water was collected with a 301 Niskin bottle from $300 \mathrm{~m}$ depth, filled into a 201 polypropylene carboy (covered in black plastic foil to reduce light exposure), and brought back to the laboratory within $<1.5 \mathrm{~h}$. Temperature, salinity, and oxygen data were provided by the Service d'Observation en Milieu Littoral (SOMLIT) program and obtained using a CTD (SBE 25) with specific probes (Seabird SBE 3, 4, and 43). Samples were collected between 29 September 2008 and 9 November 2009. Monthly sampling was initially intended, but due to adverse meteorological conditions and occasional logistical problems, samples could only be collected on 10 occasions. On average, sampling was achieved every $46 \mathrm{~d}$ (range: $24-77 \mathrm{~d}$ ) during the $433 \mathrm{~d}$ period.

\section{Stratification and mixed layer depth}

The stratification index was calculated as the average density difference $\mathrm{m}^{-1}$ (Bustillos-Guzmán et al. 1995). The mixed layer depth (MLD) was estimated by a temperature criterion of $0.5^{\circ} \mathrm{C}$ (MLD-T) and a density criterion of $0.01 \mathrm{~kg} \mathrm{~m}^{-3}$ (MLD-Sigma) as described by Lukas \& Lindstrom (1991) as specified for the NW Mediterranean Sea (Herrmann \& Somot 2008, Marsaleix et al. 2008). 


\section{$\mathrm{pH}$ and $\mathrm{pCO}_{2}$}

$\mathrm{pH}$ was measured at in situ temperature with a glass electrode (Metrohm LL Unitrode) calibrated on the total scale, using Tris and AMP buffers, prepared according to Dickson et al. (2007) at a salinity of 38. Duplicate samples were taken for $\mathrm{pH}$ measurements and measured within $2 \mathrm{~h}$. The samples for total alkalinity (TA) were poisoned with saturated mercuric chloride $\left(\mathrm{HgCl}_{2}\right.$; Dickson et al. 2007) and stored in the dark at $4{ }^{\circ} \mathrm{C}$ pending analysis. TA was determined from triplicate $25 \mathrm{ml}$ sub-samples, using a computercontrolled Gran titration technique with a 713 Metrohm pH-meter and a 665 Metrohm Dosimat. The $\mathrm{pCO}_{2}$ as well as the other parameters of the carbonate chemistry were calculated using the R package seacarb (Lavigne \& Gattuso 2010) from measured values of $\mathrm{pH}, \mathrm{TA}$, temperature, and salinity.

\section{Nutrients and organic carbon}

For nutrients, water samples $(10 \mathrm{ml})$ were filtered through polycarbonate filter membranes (pore size, $0.2 \mu \mathrm{m}$ ) and poisoned immediately after filtration with $\mathrm{HgCl}_{2}$ (Suprapur quality; final concentration, $20 \mu \mathrm{g}$ $\mathrm{ml}^{-1}$ ) to limit the bacterial consumption of nutrients. Samples were stored frozen until analysis. Nitrite $\left(\mathrm{NO}_{2}\right)$ and nitrate $\left(\mathrm{NO}_{3}\right)$ concentrations were measured by colorimetry using an AA3 Bran \& Luebbe autoanalyzer (Strickland \& Parsons 1972). The detection limits (using a light path of $10 \mathrm{~cm}$ ) were $0.05 \mu \mathrm{mol}$ $\mathrm{l}^{-1}$ for nitrate and $0.01 \mu \mathrm{mol} \mathrm{l}^{-1}$ for nitrite.

For total organic carbon (TOC), $10 \mathrm{ml}$ samples were filled in pre-combusted $\left(450^{\circ} \mathrm{C}\right.$ for $\left.24 \mathrm{~h}\right)$ glass tubes and acidified with $12 \mu \mathrm{l}$ of $85 \%$ phosphoric acid (Merck Chemicals). Tubes were closed with Teflonlined screw caps and stored in the dark at room temperature pending analysis. TOC was analyzed using the high temperature catalytic oxidation technique (Benner \& Strom 1993) using a Shimadzu TOC-V analyzer and an international certified reference sample for dissolved organic carbon (DOC) concentration. Analytical precision of the measurements was better than $2 \%$ coefficient of variation $(\mathrm{CV})$.

\section{Transparent exopolymeric particles and carbon content}

Water samples $(50 \mathrm{ml})$ were collected from each experiment with polypropylene tubes, fixed with $37 \%$ buffered formaldehyde $(1 \%$ final concentra- tion), and stored at $4^{\circ} \mathrm{C}$ pending analysis. Aliquots of 15 to $25 \mathrm{ml}$ were gently filtered through $0.2 \mu \mathrm{m}$ poresize white polycarbonate filters (Nuclepore ${ }^{\mathrm{TM}}$ ) under low pressure and stained with $500 \mu \mathrm{l}$ of an aqueous solution of $0.06 \%$ acetic acid ( $\mathrm{pH} 2.5)$ and $0.02 \%$ Alcian blue 8GX. Filters were mounted directly on a white slide (Cyto-Clear ${ }^{\circledR}$ ). Transparent exopolymeric particles (TEP) were counted and sized at 200x and 400× magnification using an Zeiss Axiophot microscope coupled with an image analysis system (Beauvais et al. 2003). The carbon content of TEP was determined from the obtained size-frequency distribution by using a size-dependent relationship (Mari 1999).

\section{Enumeration of prokaryotes, viruses, and flagellates}

Water samples for the enumeration of prokaryotes and viruses were preserved with glutaraldehyde $\left(0.5 \%\right.$ final concentration) for $30 \mathrm{~min}$ at $4^{\circ} \mathrm{C}$, then flash frozen in liquid nitrogen and stored at $-80^{\circ} \mathrm{C}$ until analysis. Prokaryotes and viruses were stained with SYBR Green I (Molecular Probes) and subsequently analyzed using a FACSCalibur flow cytometer (BD Biosciences) as described previously (Gasol \& del Giorgio 2000, Brussaard 2004). Populations of prokaryotes, i.e. high nucleic acid (HNA) and low nucleic acid prokaryotes were distinguished on plots of side scatter versus green fluorescence $(530 \mathrm{~nm}$ wavelength, fluorescence channel 1 of the instrument). Viral flow cytometer (FCM) subgroups V1, V2, and V3 were distinguished by increasing fluorescence intensity (Brussaard et al. 2010). Data analysis was performed using the BD Cell Quest Pro software (version 4.0.2; BD Biosciences).

The abundance of heterotrophic flagellates was determined by epifluorescence microscopy. Water samples $(100 \mathrm{ml})$ were fixed with glutaraldehyde (final concentration $1 \%$ ) and immediately filtered on black polycarbonate filters $(0.8 \mu \mathrm{m}$ pore size, $25 \mathrm{~mm}$ diameter). Filters were stained with a solution of 4', 6'-diamidino-2-phenylindole (final concentration $0.5 \mu \mathrm{g} \mathrm{ml}{ }^{-1}$; Thermo Scientific), mounted on slides, and stored frozen until counting (Sherr et al. 1993).

\section{Respiration}

Water samples for CR were distributed into calibrated $60 \mathrm{ml}$ borosilicate bottles taking care to avoid 
air bubbles. Three replicates were fixed immediately and used to determine the initial oxygen concentration at $0 \mathrm{~h}$ and another 3 bottles were fixed after $24 \mathrm{~h}$ incubation to determine the oxygen concentration at the end of the incubations. CR was estimated by calculating the linear decrease of $\mathrm{O}_{2}$ concentrations versus time. PR was determined in the same way after gentle prefiltration of the samples through a $0.8 \mu \mathrm{m}$ pore size polycarbonate filter (diameter $47 \mathrm{~mm}$, Whatman). Incubations were carried out in the dark at in situ temperature $\left(13^{\circ} \mathrm{C}\right)$ for $24 \mathrm{~h}$. Dissolved oxygen was measured using a potentiometric titration (Anderson et al. 1992) with an Orion redox electrode (9778SC) and a custom built titrator. Reagents and standardization were otherwise similar to those described by Knap et al. (1996). Analytical precision of the respiration measurements averaged $19 \%$ CV for mesopelagic samples. Prokaryotic abundance did not change systematically during the incubation period of $24 \mathrm{~h}$ in the mesopelagic samples (data not shown).

\section{DNA extraction and purification}

Water samples (ca. 1 l) were filtered onto $0.2 \mu \mathrm{m}$ polycarbonate filters (47 mm, Nuclepore) and stored at $-80^{\circ} \mathrm{C}$ until analysis. The HEATSALT protocol was used to extract DNA (Hansson et al. 2009). Briefly, the protocol combines a heat/salt lysis with a simultaneous salt extraction step ( $\mathrm{NaCl}$ and $80^{\circ} \mathrm{C}$ for $30 \mathrm{~min}$ ). Nucleic acids were then precipitated with isopropanol. The extracted DNA was further purified using a desalting and DNA concentration kit (QiaExII, Qiagen) according to the manufacturer's protocol.

\section{PCR and denaturing gradient gel electrophoresis (DGGE) analysis}

The conditions of the touchdown PCR and chemicals were as described by Schäfer \& Muyzer (2001). Between 1 and $4 \mu \mathrm{l}$ of cleaned nucleic acid extract were used as template in a $50 \mu \mathrm{PCR}$ reaction (1.5 $\mathrm{mM} \mathrm{MgCl}_{2}, 0.25 \mu \mathrm{M}$ of each primer, and $2.5 \mathrm{U}$ Taq polymerase; Sigma) together with a positive and a negative control. A fragment of the $16 \mathrm{~S}$ rRNA gene was amplified using the primer pairs 341F-GC/ 907R and 344F-GC/ 915R for Bacteria and Archaea, respectively (Casamayor et al. 2000, Schäfer \& Muyzer 2001). The bacterial primers were slightly modified to also detect Gammaproteobacteria (Sánchez et al. 2007).
DGGE was performed as described by Schäfer \& Muyzer (2001). PCR products (500 ng) were separated into bands by electrophoresis for $18 \mathrm{~h}$ at $100 \mathrm{~V}$ on acrylamide/bis-acrylamide (6\%) gels prepared using a gradient of 30 to $70 \%$ (urea and formamide) and a INGENYphorU DNA Mutation Detection System (Ingeny International). A standard made from a 2001 bacterioplankton extraction was loaded to allow for comparison of bands within gels. DGGE gels were photographed with a gel documentation system (GelDoc EQ; Bio-Rad) after 15 min of staining with a 10× SYBR Gold solution (Molecular Probes) using a variety of exposure times. Analysis of band patterns between lanes (including relative bend intensities) was performed with the Quantity One Software (BioRad). Selected samples covering all detected bands were excised. The DNA was eluted overnight in autoclaved Milli-Q water at $4{ }^{\circ} \mathrm{C}$, checked for purity by re-running it on a gel, and sequenced (MWGBiotech). Sequences were edited using the freeware program 4Peaks 1.6 (http://nucleobytes.com/index. php/4peaks) and a BLAST search (http://blast.ncbi. nlm.nih.gov/BLAST.cgi).

\section{Statistical analysis}

The seasonal variability of parameters was assessed as \%CV calculated by dividing the standard deviation by the mean. Cluster analysis of DGGE banding patterns was performed using the unweighted pair group method with arithmetic mean. The Bray-Curtis similarity was used, which includes the relative intensity of each band.

Potential relationships among variables were tested by linear pairwise correlations (Spearman correlation analysis). Key parameters were used to perform principal component analysis (PCA). Data were $\log (+1)$ transformed to satisfy the requirements of normality and homogeneity of variance necessary for parametric statistics. Only factors with an eigenvalue $>1$ were retained. Statistical analyses were performed with the Aabel 3 or the R program.

\section{RESULTS}

\section{Characterization of the water column}

In Fig. 1, typical depth profiles of temperature, salinity, and potential density $\left(\sigma_{t}\right)$ from surface water to $300 \mathrm{~m}$ water depth at Point $\mathrm{C}$ are shown for the 3 identified periods. Density changes were driven 

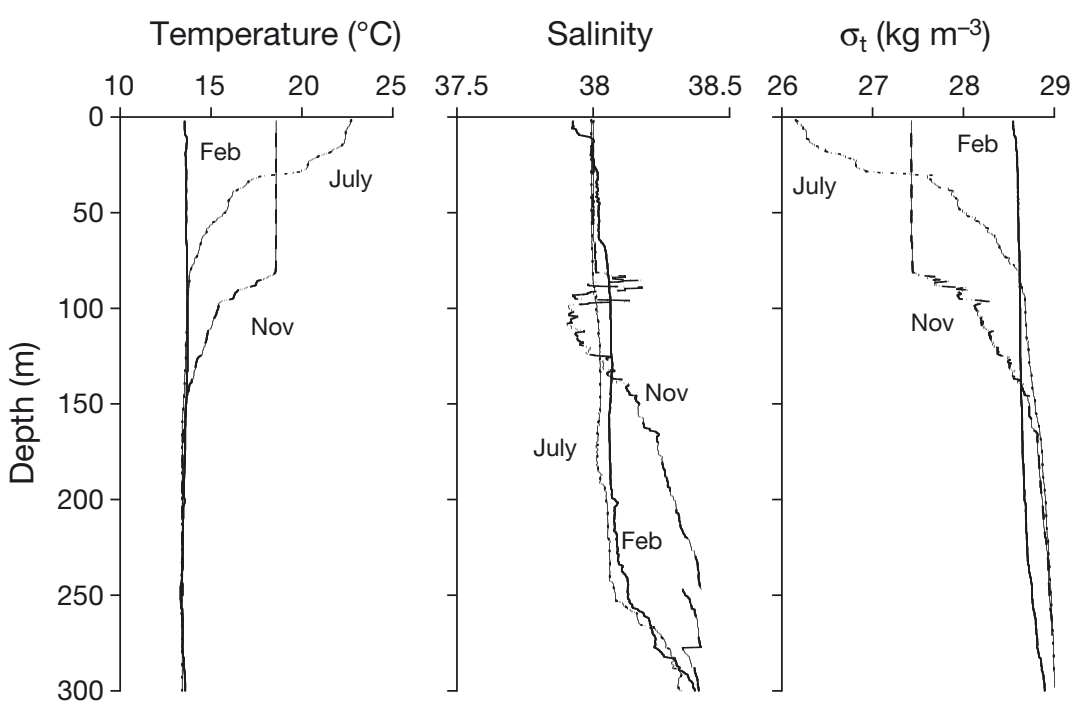

Fig. 1. Depth profiles of temperature, salinity, and potential water density $\left(\sigma_{t}\right)$ representative for the 3 main stratification periods (see Fig. 2) at Point $C$ in the NW Mediterranean Sea. All profiles are from 2009

by temperature as in the nearby Bay of Villefranche (Bonilla-Findji et al. 2010). MLD varied from ca. $12 \mathrm{~m}$ (during summer stratification) to $268 \mathrm{~m}$ (MLD-Sigma) and $300 \mathrm{~m}$ (MLT-T), i.e. down to (almost) the entire investigated water column (winter mixing; Fig. 2). Based on a stratification index (potential water density), 3 types of periods differing with respect to water column stability were identified for sur-

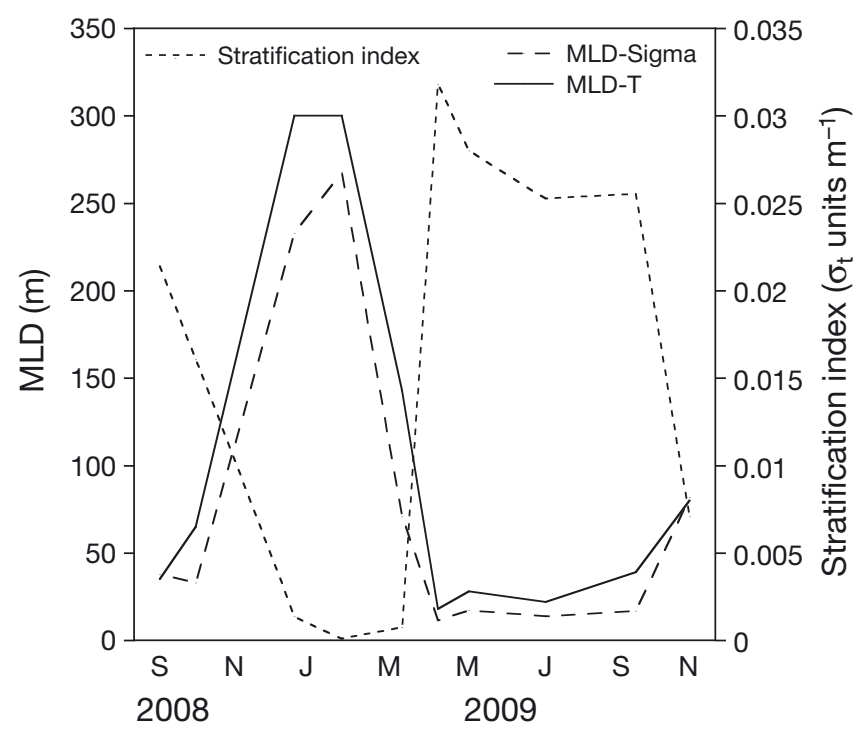

Fig. 2. Hydrological conditions during the study period at Point C in the NW Mediterranean Sea (down to $300 \mathrm{~m}$ ) as estimated by the mixed layer depth (MLD) and the water stratification index. MLD was estimated by a temperature criterion of $0.5^{\circ} \mathrm{C}$ (MLD-T) and a density criterion of $0.01 \mathrm{~kg} \mathrm{~m}^{-3}$ (MLD-Sigma) face water of Point C: (1) a summer stratified period, (2) a mixed period, and (3) semi-mixed periods (for spring and fall-winter conditions; Fig. 2). The semi-mixed periods were very short. MLD-T and MLD-Sigma were strongly correlated $(\rho=0.978)$, and both parameters were negatively related with water stratification $(\rho \geq$ $0.800)$.

\section{Physicochemical characterization of the study site}

Averages, ranges, and \% CV of the physicochemical parameters of data from Point C $(300 \mathrm{~m})$ are summarized in Table 1. During the observation period, temperature and salinity varied little from 13.3 to $13.6^{\circ} \mathrm{C}(0.7 \%$ $\mathrm{CV})$ and 38.30 to $38.52(0.2 \% \mathrm{CV})$, respectively. Potential density also varied little and ranged from 28.89 to $29.01 \mathrm{~kg} \mathrm{~m}^{-3}(1.5 \% \mathrm{CV})$. Potential density dropped from the start of study period until February 2009 and showed a net increase afterwards (Fig. 3A). Changes in $\sigma_{\mathrm{t}}$ were likely driven by salinity, since there was only a significant correlation between salinity and water density but not between temperature and density (see below). The $\mathrm{pH}$ (total scale) values varied slightly and ranged from 8.034 to $8.101(0.3 \% \mathrm{CV})$, whereas the $\mathrm{pCO}_{2}$ levels ranged from 381 to $452 \mu \mathrm{atm}(5 \% \mathrm{CV})$. The levels of $\mathrm{pCO}_{2}$ showed 3 maxima in January, May, and September 2009. The values were lower in 2008 than in 2009 (Fig. 3B).

Nitrate concentrations, which are only available for 2009, varied from 5.8 to $7.7 \mu \mathrm{mol} \mathrm{l} \mathrm{l}^{-1}$ (Table 1). Nitrate concentrations showed a maximum in February 2009 and were again high between July and November 2009 (Fig. 3C). Eighty percent of the nitrite values were below the detection limit. TOC concentrations varied from 56.6 to $67.0 \mu \mathrm{mol} \mathrm{l}^{-1}$, and the number of TEP varied from $(0.5$ to 1.4$) \times 10^{6}$ particles $l^{-1}$. TOC concentrations remained stable until February 2009, showed a minimum in March, a maximum in May, and decreased again afterwards (Fig. 3C). TEP abundance varied irregularly, whereas TEP volume concentration showed 3 peaks (Fig. 3D). The estimated carbon stored in TEP contributed only little to TOC (average, $1.0 \%$; range, $0.3-1.8 \%$; data not shown). Nutrient and organic matter concentrations showed CVs ranging from 10 to $49 \%$. 
Table 1. Physicochemical parameters (CV: coefficient of variation) at Point C in the NW Mediterranean Sea (300 m). Sample number was 10 except for inorganic nutrients, where $\mathrm{n}=8$. $\sigma_{\mathrm{t}}$ : water density; $\mathrm{pH}_{\mathrm{T}}$ : $\mathrm{pH}$ measured on a total scale; TOC: total organic carbon; TEP-No: transparent exopolymeric particles (TEP) abundance; TEP-conc: TEP volume concentration

\begin{tabular}{|lccccccccc|}
\hline & $\begin{array}{c}\text { Temp } \\
\left({ }^{\circ} \mathrm{C}\right)\end{array}$ & Salinity & $\begin{array}{c}\sigma_{\mathrm{t}} \\
\left(\mathrm{kg} \mathrm{m}^{-3}\right)\end{array}$ & $\mathrm{pH}_{\mathrm{T}}$ & $\begin{array}{c}\mathrm{pCO}_{2} \\
(\mu \mathrm{atm})\end{array}$ & $\begin{array}{c}\mathrm{NO}_{3} \\
\left(\mu \mathrm{mol} \mathrm{l}^{-1}\right)\end{array}$ & $\begin{array}{c}\mathrm{TOC} \\
\left(\mu \mathrm{Hmol}^{-1}\right)\end{array}$ & $\begin{array}{c}\text { TEP-No } \\
\left(10^{6} \mathrm{l}^{-1}\right)\end{array}$ & $\begin{array}{c}\mathrm{TEP}-\mathrm{conc} \\
(\mathrm{ppm})\end{array}$ \\
\hline Mean & 13.4 & 38.43 & 28.97 & 8.070 & 409 & 6.9 & 56.6 & 0.98 & 0.30 \\
Min. & 13.3 & 38.30 & 28.89 & 8.034 & 381 & 5.8 & 49.3 & 0.52 & 0.15 \\
Max. & 13.6 & 38.52 & 29.01 & 8.101 & 452 & 7.7 & 67.0 & 1.4 & 0.56 \\
CV $(\%)$ & 0.7 & 0.2 & 1.5 & 0.3 & 5.4 & 9.6 & 9.5 & 36.5 & 49.0 \\
\hline
\end{tabular}
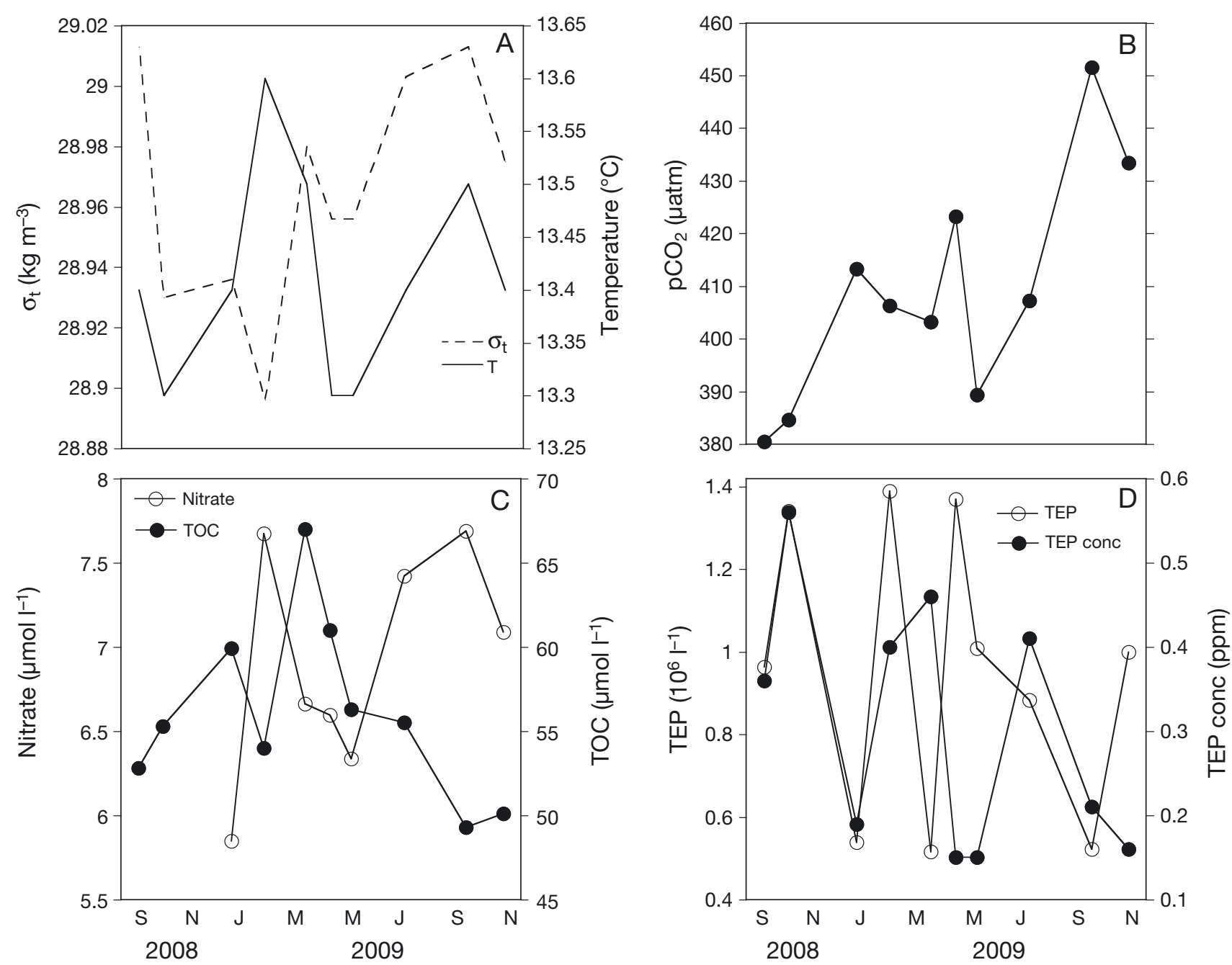

Fig. 3. Variation of physicochemical parameters in the mesopelagic zone at Point $\mathrm{C}$ in the NW Mediterranean Sea (300 $\mathrm{m}$ water depth) on a seasonal time scale. (A) Temperature and potential water density $\left(\sigma_{t}\right.$ note that salinity profiles were almost identical to those of potential density). (B) $\mathrm{pCO}_{2}$ levels. (C) Nitrate and total organic carbon (TOC) concentrations. (D) Transparent exopolymeric particle concentrations (TEP conc) and TEP abundance

\section{Microbial abundances and rates}

Averages, ranges, and \% CV data of the microbial parameters of data from Point C (300 m) are sum- marized in Table 2. Prokaryotic abundance ranged from $(1.6$ to 3.1$) \times 10^{8}$ cells $1^{-1}$ and varied by $22 \%$ CV. Prokaryotic abundance increased from September 2008 to January 2009, dropped to the low- 
Table 2. Means, minima, maxima, and coefficients of variation (CV) of microbial parameters at Point C in the NW Mediterranean Sea $(300 \mathrm{~m})$. PA: prokaryotic abundance; HNA: high nucleic acid prokaryotes; VA: viral abundance; V1-V3: viral flow cytometer subgroups; VPR: virus:prokaryote ratio; FA: flagellate abundance; CR: community respiration. Sample number was 10. The number of bands in the denaturing gradient gel electrophoresis analysis is also shown

\begin{tabular}{|lccccccccccc|}
\hline & PA & HNA & VA & V1 & V2 & V3 & VPR & FA & CR $(\mu m o l$ & No. of bands \\
$\left(10^{8} 1^{-1}\right)$ & $(\%)$ & $\left(10^{9} \mathrm{l}^{-1}\right)$ & $(\%)$ & $(\%)$ & $(\%)$ & & $\left(10^{5} \mathrm{l}^{-1}\right)$ & $\left.\mathrm{O}_{2} \mathrm{l}^{-1} \mathrm{~d}^{-1}\right)$ & Bacteria \\
Archaea
\end{tabular}

est values in February 2009, increased again until May, and dropped again afterwards to values similar to February 2009 (Fig. 4A). Percent HNA ranged from 62 to $73 \%$. Percent HNA dropped from Sep- tember to October 2008; afterwards, \%HNA values were high between February and July and increased even more towards the end of the survey period (Fig. 4A).
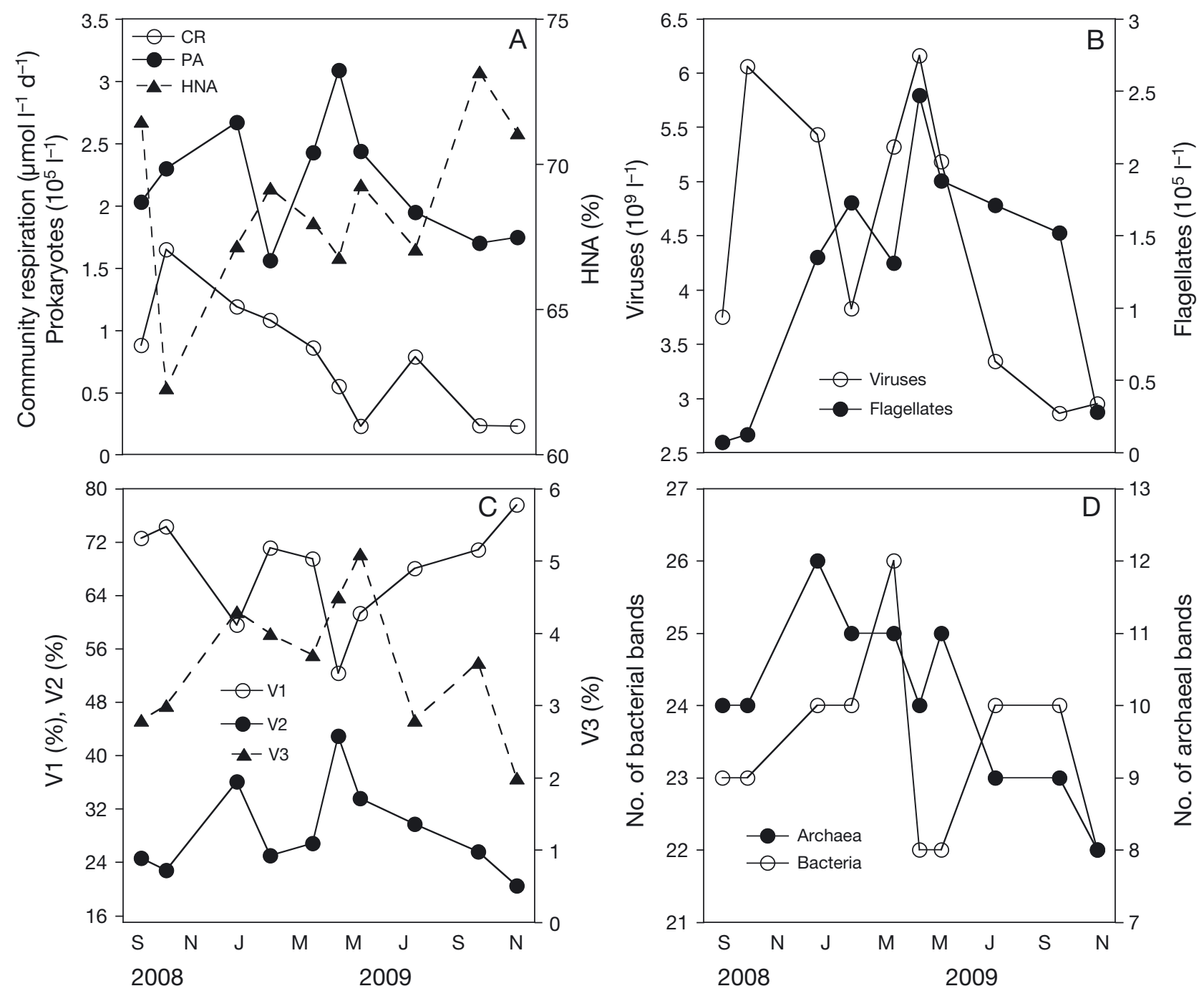

Fig. 4. Variation of microbial parameters in the mesopelagic zone at Point C in the NW Mediterranean Sea (300 $\mathrm{m}$ water depth) on a seasonal time scale. (A) Prokaryotic abundance (PA), percentage of high nucleic acid prokaryotes (HNA), and community respiration (CR) rates. (B) Viral and flagellate abundance. (C) Percentage of viral subgroups (V1-V3). (D) Number of bacterial and archaeal bands 
Viral abundance ranged from (2.9 to 6.2$) \times 10^{9}$ particles $\mathrm{l}^{-1}$ and varied by $28 \% \mathrm{CV}$. Viral abundance increased from September to October 2008, decreased afterwards until March 2009, showed a second maximum in April 2009, and decreased again thereafter until June 2009, when the lowest values were found (Fig. 4B). V1 was the dominant viral FCM group, ranging from 53 to $78 \%$ of observed viral particles: V2 ranged from 21 to $43 \%$ and V3 from 2 to $5 \%$. V1 showed 2 minima, one in January 2009, the other in May/June 2009; values were roughly similar at other time points. The pattern for V2 was inverse to that of V1. V3 increased from September 2008 to January 2009, decreased slightly until April, followed by a second increase until June; a constant decrease was observed thereafter (Fig. 4C). The viral populations varied by 11 to $27 \% \mathrm{CV}$. The virus:prokaryote ratio (VPR) varied from 12 to $26(16 \% \mathrm{CV})$. Flagellate

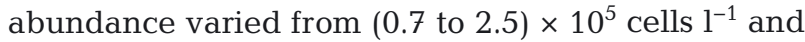
showed a large variability of $66 \% \mathrm{CV}$. Flagellate abundance increased from September 2008 to May 2009 and then decreased until the end of the investigation period to values only slightly higher than in 2008 (Fig. 4B).

$\mathrm{CR}$ ranged from 0.23 to $1.65 \mu \mathrm{mol} \mathrm{O} \mathrm{O}^{-1} \mathrm{~d}^{-1}$ and varied by $61 \% \mathrm{CV}$. CR increased strongly from September to October 2008 and later showed a rough net decrease with the exception of a small maximum in June 2009; lowest values were found at the last sampling. PR was only measured at 4 stations and averaged $58 \%$ of CR (range: $22-91 \%$ ).

\section{Bacterial and archaeal community fingerprints}

Between 22 and 26 DGGE bands were detected per sample for Bacteria and between 8 and 12 bands for Archaea. We found 30 different bacterial and 12 archaeal bands. Sixteen bacterial (53\% of total bacterial bands) and 7 archaeal bands (58\% of total archaeal bands) were present at all time points (Tables A1 \& A3 in Appendix 1). The variability of the number of bands was $6 \%$ for Bacteria and $13 \%$ for Archaea. The number of bacterial bands increased from October 2008 to April 2009, decreased until June 2009, and then increased again to levels similar to fall 2008 (Fig. 4D). The number of archaeal bands increased strongly from October 2008 to January 2009, followed by a rough net decrease; the lowest values were found at the last sampling (Fig. 4D).

Bacterial community composition showed a clear seasonal pattern. The first 3 samples (October 2008 to February 2009) clustered together (Fig. 5A). The sec- ond cluster (remaining samples) clustered into 2 groups, i.e. April-May 2009 and July-November 2009. It is noteworthy that the fall samples from 2008 and 2009 did not cluster together. Archaea showed a different seasonal clustering. The first cluster comprised samples collected between July and November 2009. The second cluster showed 2 non-season specific subclusters: January and May 2009 and the rest of the samples.

Of the bacterial bands, 22 could be sequenced (Table A2 in Appendix 1). Seven belonged to Alpha-
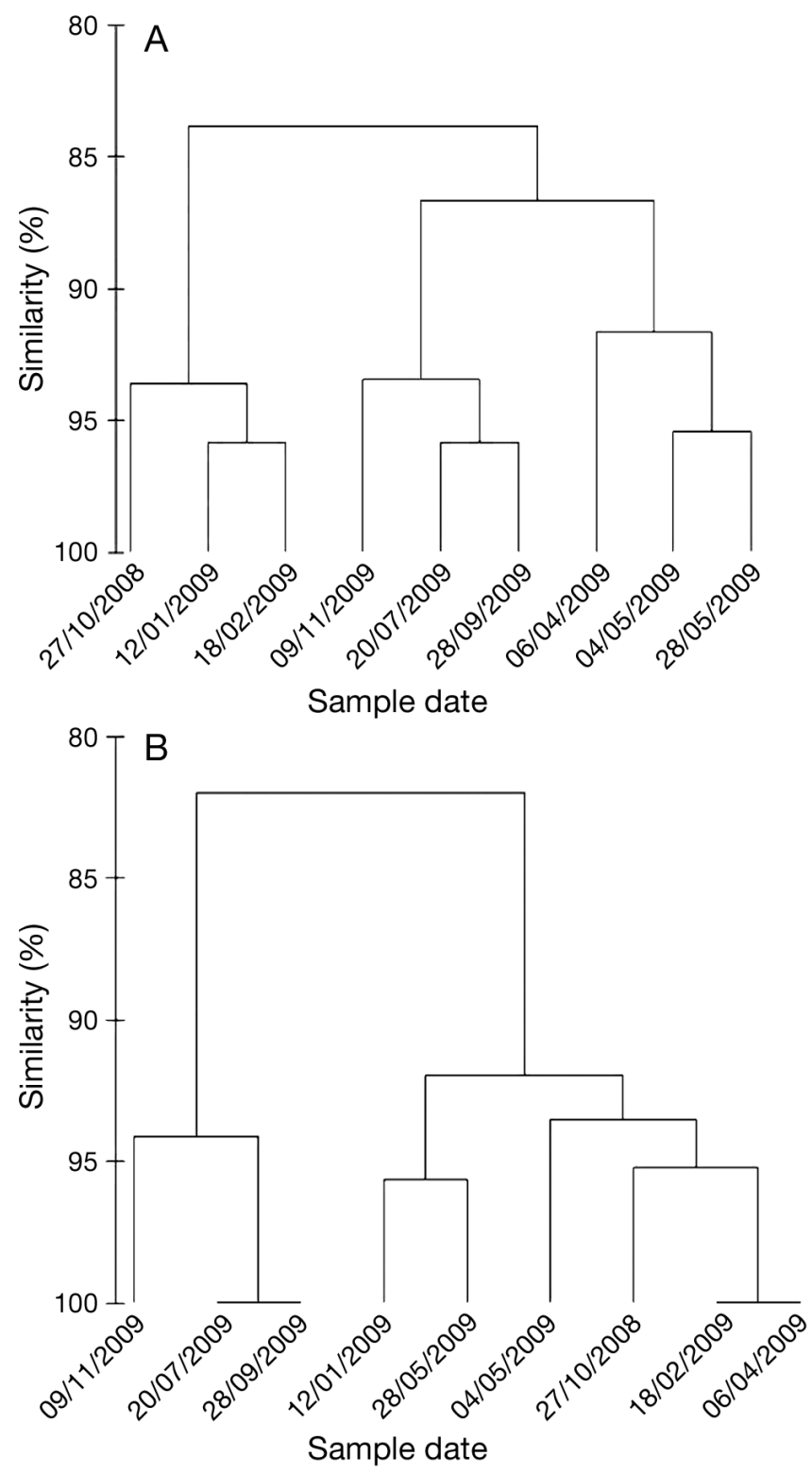

Fig. 5. Cluster analysis of banding patterns of bacterial and archaeal communities obtained by denaturing gradient gel electrophoresis from Point $C$ in the NW Mediterranean Sea (300 m). (A) Bacteria, (B) Archaea 
proteobacteria, 6 to Gammaproteobacteria, 4 to Deltaproteobacteria (2 to Chloroflexi), and 1 to Actinobacteria. Four sequences could not be characterized further. Sequence similarity with known sequences from isolates and environmental samples ranged from 73 to $99 \%$. Two sequences with $\leq 75 \%$ similarity came from a site in the Mediterranean Sea (DYFAMED) ca. $50 \mathrm{~km}$ away from the study site. Nine archaeal bands could be successfully sequenced and all belonged to Euryarchaeota (Table A4 in Appendix 1). Sequence similarity for Archaea ranged from 85 to $99 \%$. The closest sequences for Archaea were all from 131 to $3100 \mathrm{~m}$ water depth.

\section{Relationships among parameters}

A correlation analysis (Spearman's $\rho$ ) was calculated for all parameters; those with significant correlations are presented in Table 3. This analysis showed a positive relationship between salinity and water density. Also, TOC concentrations increased with temperature and decreased with water stratification. TEP abundance decreased with water density, and TEP concentrations increased with temperature.

Temperature was not significantly related to biological parameters. Prokaryotic and viral abundance were negatively related to nitrate concentrations. CR was negatively related to salinity and water density. The number of DGGE bands for the bacterial community (NBB) was inversely related to TOC and directly to TEP concentrations.
Several correlations were found among biological parameters. CR and prokaryotic and viral abundance were positively related. Besides correlations between different viral populations (data not shown), $\%$ V1 decreased with prokaryotic abundance and \%V2 increased with prokaryotic abundance (Fig. 6). Percent V1 also decreased with flagellate abundance, whereas \%V2 and \%V3 increased with it (Fig. 7). V3 increased with the number of archaeal bands (Fig. 8).

\section{Integrated view of data: PCA}

Based on the correlation analysis (Table 3), key parameters, namely TOC concentration, TEP parameters, prokaryotic and viral and flagellate abundance, CR, and NBB, as well as water density and stratification index were selected for PCA. Four significant components were extracted, explaining $93 \%$ of the total variation (Table 4). A large portion of the variation in the mesopelagic system was characterized by the first component (PCA-C1; 37\%), where NBB was strongly correlated with TOC, TEP concentration, and stratification index. The second component (PCA-C2), which explained $28 \%$ of the variation, showed a negative correlation of water density on the one hand and prokaryotic and viral abundance and $\mathrm{CR}$ on the other hand. The third component (PCA-C3; 17\%) showed a negative correlation between prokaryotic abundance and TEP abundance. The fourth component (PCA-C4; $11 \%$ ) related water stratification with TEP concentration.

Table 3. Correlation coefficients (Spearman's $\rho$ ) for physicochemical and biological parameters from Point C in the NW Mediterranean Sea $(300 \mathrm{~m})$ including water stratification of surface water. Only those parameters are shown for which significant correlations were found $(p<0.05)$. Significant values are in bold $\left({ }^{*} p<0.05,{ }^{* *} p<0.01,{ }^{* * *} p<0.005\right)$. $\sigma_{t}$ : water density; Strat: water stratification index; TOC: total organic carbon; TEP-No: transparent exopolymeric particle (TEP) abundance; TEP-conc: TEP volume concentration; PA: prokaryotic abundance; VA: viral abundance; VPR: virus:prokaryote ratio; CR: community respiration; NBB: number of bacterial bands in the denaturing gradient gel electrophoresis analysis

\begin{tabular}{|c|c|c|c|c|c|c|c|c|c|c|c|}
\hline & Temperature & Salinity & $\sigma_{\mathrm{t}}$ & Strat & Nitrate & TOC & TEP-No & TEP-conc & PA & VA & $\mathrm{CR}$ \\
\hline Salinity & 0.495 & & & & & & & & & & \\
\hline$\sigma_{\mathrm{t}}$ & 0.226 & $0.939^{* * *}$ & & & & & & & & & \\
\hline Strat & -0.499 & 0.256 & 0.366 & & & & & & & & \\
\hline Nitrate & 0.707 & 0.563 & 0.467 & -0.191 & & & & & & & \\
\hline TOC & $0.669^{*}$ & -0.146 & -0.037 & $-0.673^{*}$ & -0.452 & & & & & & \\
\hline TEP-No & -0.109 & -0.506 & $-0.640^{*}$ & 0.055 & 0.218 & 0.442 & & & & & \\
\hline TEP-conc & $0.634^{*}$ & 0.080 & -0.006 & -0.553 & 0.048 & -0.571 & 0.067 & & & & \\
\hline $\mathrm{PA}$ & -0.590 & -0.354 & -0.195 & 0.333 & $-0.881^{* * *}$ & -0.195 & -0.079 & -0.455 & & & \\
\hline VA & -0.158 & -0.311 & -0.152 & -0.164 & $-0.714^{*}$ & 0.006 & -0.151 & 0.346 & $0.634^{*}$ & & \\
\hline CR & -0.146 & $-0.677^{*}$ & $-0.626^{*}$ & -0.321 & -0.310 & -0.055 & 0.188 & 0.491 & $0.658^{*}$ & $0.657^{*}$ & \\
\hline NBB & 0.534 & 0.267 & 0.223 & -0.612 & 0.267 & $-0.816^{* *}$ & -0.585 & $0.630^{*}$ & -0.275 & 0.151 & 0.257 \\
\hline
\end{tabular}



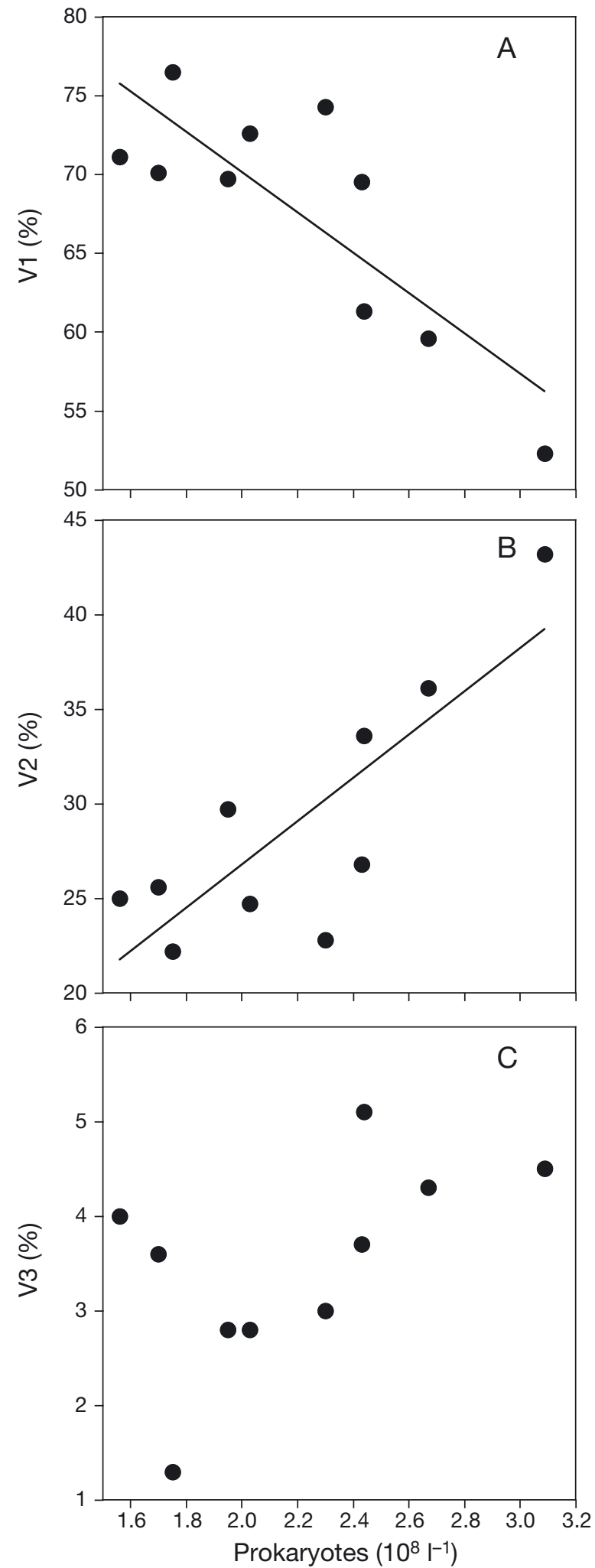

Fig. 6. Relationships between prokaryotic abundance and the relative contribution of viral populations from Point $\mathrm{C}$ in the NW Mediterranean Sea (300 m). (A) Viral subgroup 1 (V1), (B) V2, (C) V3. For significant $p$ values $(p<0.05)$, a tendency line is shown
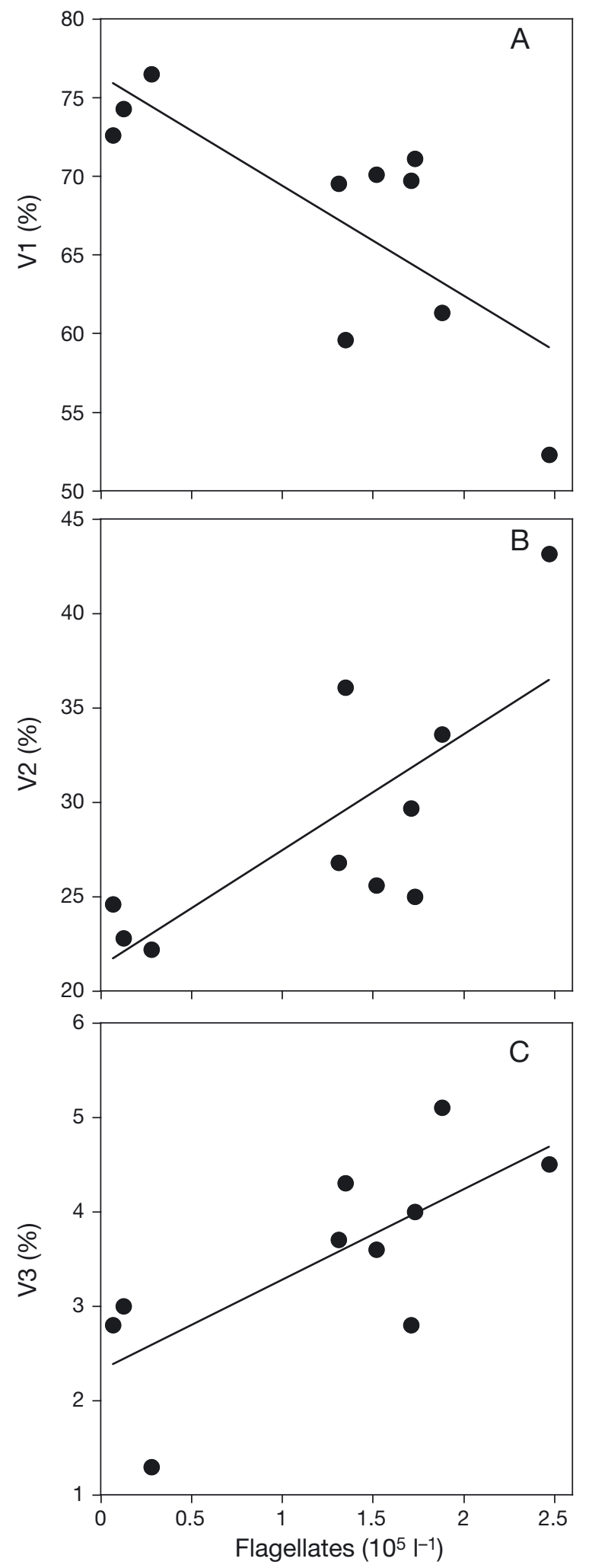

Fig. 7. Relationships between flagellate abundance and the relative contribution of viral populations from Point $C$ in the NW Mediterranean Sea (300 m). (A) Viral subgroup 1 (V1), (B) V2, (C) V3. For significant $p$ values $(p<0.05)$, a tendency line is shown 


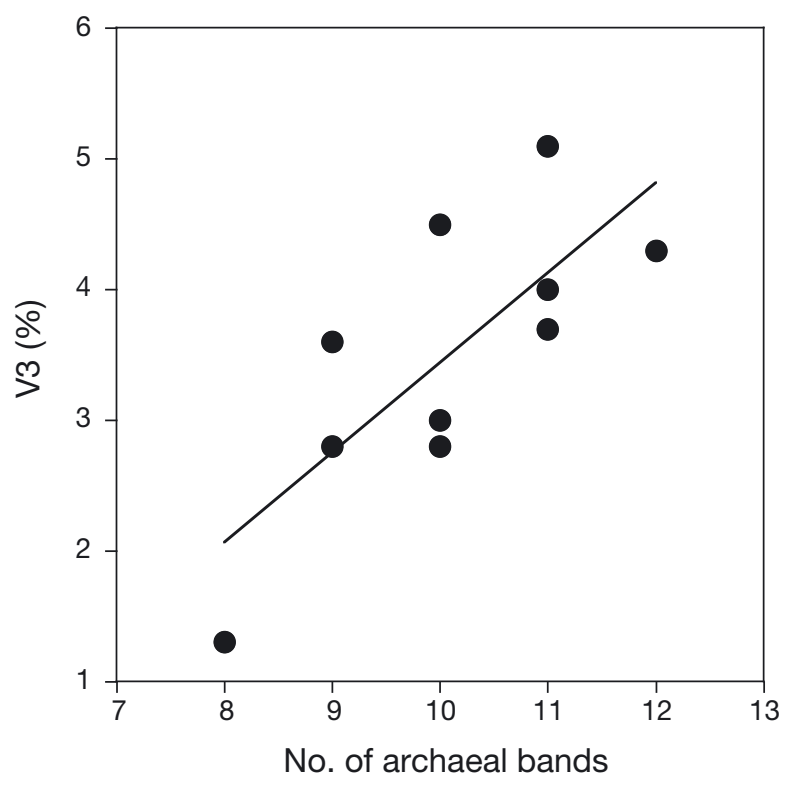

Fig. 8. Relationship between the number of archaeal bands in the denaturing gradient gel electrophoresis analysis and the relative contribution of viral population V3 from Point C in the NW Mediterranean Sea $(300 \mathrm{~m})$. A tendency line is shown for the significant correlation between the 2 parameters $(p<0.05)$

\section{DISCUSSION}

\section{Characterization of the water column}

The classification of the water stratification into 3 periods at Point $C$ was similar to Point $B$ in the nearby Bay of Villefranche (Bustillos-Guzmán et al. 1995). The MLD extended down to ca. $300 \mathrm{~m}$. This is in accordance with the finding that the water column in the Mediterranean Sea is completely mixed in winter (albeit sometimes only for short periods). This deep mixing might influence the concentrations, abundances, and rates of the measured parameters in deeper water at a seasonal scale.

\section{Dynamics of physicochemical parameters}

$\mathrm{pH}$ and $\mathrm{pCO}_{2}$ values from Point $\mathrm{C}(300 \mathrm{~m})$ were within the range of data found for the mesopelagic layer in the Mediterranean at the DYFAMED station $50 \mathrm{~km}$ off the Bay of Villefranche (Copin-Montégut \& Bégovic 2002). Changes in $\mathrm{pH}$ and $\mathrm{pCO}_{2}$ at Point $\mathrm{C}$ were comparatively small, and values were not related to other parameters. In experiments using much stronger changes of $\mathrm{pH}$ and $\mathrm{pCO}_{2}$ than observed at Point $\mathrm{C}$, significant effects were only
Table 4. Component matrix for Point C in the NW Mediterranean Sea. Extraction method was principal component analysis (PCA) from Point C (300 m) including water stratification of surface water. Data set for PCA was reduced to 9 key parameters. Four components were extracted. Correlations $>0.4$ are in bold. NBB: number of bacterial bands in the denaturing gradient gel electrophoresis analysis. See Table 3 for other abbreviations

\begin{tabular}{|lrrrr|}
\hline \multirow{2}{*}{ Parameter } & \multicolumn{5}{c}{ Component } \\
\cline { 2 - 5 } & \multicolumn{1}{c}{1} & 2 & 3 & \multicolumn{1}{c}{4} \\
\hline$\sigma_{\mathrm{t}}$ & 0.126 & $\mathbf{0 . 4 7 0}$ & 0.349 & 0.398 \\
Stratification index & $\mathbf{- 0 . 4 0 1}$ & 0.104 & 0.250 & $\mathbf{- 0 . 5 4 6}$ \\
TOC & $\mathbf{0 . 4 6 0}$ & -0.173 & -0.065 & -0.006 \\
TEP abundance & 0.166 & -0.344 & $\mathbf{- 0 . 5 4 2}$ & 0.340 \\
TEP concentration & $\mathbf{- 0 . 4 2 8}$ & -0.046 & -0.095 & $\mathbf{0 . 5 5 8}$ \\
PA & 0.140 & $\mathbf{- 0 . 4 0 8}$ & $\mathbf{0 . 5 6 7}$ & -0.024 \\
VA & -0.017 & $\mathbf{- 0 . 5 5 8}$ & 0.340 & -0.026 \\
CR & -0.334 & $\mathbf{- 0 . 4 2 1}$ & 0.032 & 0.326 \\
NBB & $\mathbf{- 0 . 4 7 5}$ & 0.151 & 0.265 & -0.100 \\
\% of variance & 36.7 & 28.2 & 17.1 & 11.4 \\
Cumulative & 36.7 & 64.9 & 82.0 & 93.3 \\
\hline
\end{tabular}

found for some microbial parameters (e.g. Liu et al. 2010, Weinbauer et al. 2011). Thus, the current evidence does not suggest a significant effect of seasonal variation of $\mathrm{pH}$ and $\mathrm{pCO} 2$ on microbial abundances, diversity, and processes in the mesopelagic zone at Point $\mathrm{C}$.

Maximum nitrate concentrations were similar at Point C (300 m), in the adjacent Bay of Villefranche (0-30 $\mathrm{m}$; distance $<0.5 \mathrm{~km}$; Bonilla-Findji et al. 2010, Vandromme et al. 2011), and in the mesopelagic zone of the DYFAMED station (Marty et al. 2002). This is in accordance with the concept that the mesopelagic layer acts as a remineralization zone and that seasonal mixing replenishes surface water with nutrients. The estimated carbon stored in TEP contributed only little to TOC $(<2 \%)$, while in the euphotic zone of the adjacent bay of Villefranche it represented 2 to $15 \%$ of TOC (Beauvais et al. 2003). This finding supports studies showing that much of the sinking particulate carbon is remineralized in the euphotic or mesopelagic zone of the NW Mediterranean Sea (Turley \& Stutt 2000).

\section{Microbial abundances in the twilight zone}

During seasonal studies in the mesopelagic zone $(200-1000 \mathrm{~m})$ at the offshore station DYFAMED, prokaryotic, viral, and flagellate abundance ranged from $(0.3$ to 3.4$) \times 10^{8}$ cells $l^{-1}$, from (0.5 to 3.5$) \times 10^{9}$

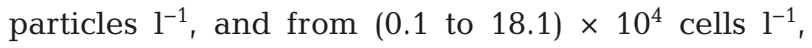


respectively; VPR ranged from 7 to 30 (Tanaka \& Rassoulzadegan 2002, Ghiglione et al. 2007, Winter et al. 2009b). Prokaryotic abundances and VPR at Point C $(300 \mathrm{~m}$; Table 2$)$ were at the higher range of abundances, or in the case of viruses and flagellates, slightly surpassed the abundances found at DYFAMED. This could be due to factors such as the shallow depth $(300 \mathrm{~m})$, export from shallow waters, or terrestrial influences such as run-off and atmospheric deposition. For example, the adjacent Bay of Villefranche could have fueled the upper mesopelagic zone at Point $\mathrm{C}$ stronger than the euphotic zone stimulated the mesopelagic zone at the DYFAMED site.

The relative proportions of $\mathrm{V} 1, \mathrm{~V} 2$, and $\mathrm{V} 3$ from the mesopelagic zone of the DYFAMED station were $56-88 \%, 11-40 \%$, and 1-5\% (Winter et al. 2009b) and thus similar to our data. Correlation analysis showed that V1 increased and V2 decreased with prokaryotic abundance at Point $\mathrm{C}$ (Fig. 6), whereas in the mesopelagic zone of DYFAMED, viral populations were not related to prokaryotic abundance (Winter et al. 2009b). During seasonal studies in the epipelagic zone of the DYFAMED station and during the stratification period in the Bay of Villefranche, V1 increased and V2 decreased with prokaryotic abundance (Bonilla-Findji 2005). This could suggest an influence of the upper mesopelagic zone at Point C by surface water.

Interestingly, \%V1 was inversely related to flagellate abundance, whereas \% V2 was positively related to flagellate abundance: thus, the relationships of these viral populations showed the same tendency as for prokaryotic abundance. This could be due to a link between protists and prokaryotes on the one hand and viruses and their prokaryotic prey on the other hand. Also, \%V3 increased with flagellate abundance, whereas we found no significant relationship with prokaryotic abundance. As there are no phytoplankton in mesopelagic waters, this relationship could indicate that the V3 group is dominated by viruses infecting heterotrophic flagellates.

\section{PR and CR in the twilight zone}

In the $\mathrm{O}_{2}$ minimum layer (350-1000 m) of the NW and NE Atlantic, PR rates were ca. $0.3 \mu \mathrm{mol} \mathrm{O} \mathrm{I}^{-1} \mathrm{~d}^{-1}$ (Reinthaler et al. 2006), and in the subtropical NE Atlantic (600-1000 m) a value of ca. $0.2 \mu \mathrm{mol} \mathrm{O}_{2} \mathrm{l}^{-1}$ $\mathrm{d}^{-1}$ was reported (Arístegui et al. 2005b). PR at Point $\mathrm{C}(300 \mathrm{~m})$ averaged $0.6 \mu \mathrm{mol} \mathrm{O}_{2} \mathrm{l}^{-1} \mathrm{~d}^{-1}$ and was thus well within the seasonal range of $\mathrm{PR}$ in the surface water $(0-30 \mathrm{~m})$ of the adjacent Bay of Villefranche (0.03-3.1 $\mathrm{mmol} \mathrm{O}_{2} \mathrm{l}^{-1} \mathrm{~d}^{-1}$; Bonilla-Findji et al. 2010) and in epipelagic water $(0-130 \mathrm{~m})$ at DYFAMED (0-3.2 $\mathrm{mol} \mathrm{O}_{2} \mathrm{l}^{-1} \mathrm{~d}^{-1}$; Lemée et al. 2002). Also, PR in the Atlantic was not different between epipelagic and mesopelagic water (Arístegui et al. 2005b, Reinthaler et al. 2006).

In the open ocean of the Gulf of Mexico, CR rates of 1.2 to $3.4 \mu \mathrm{mol} \mathrm{O} \mathrm{I}^{-1} \mathrm{~d}^{-1}$ were measured in 250 to $500 \mathrm{~m}$, and CR decreased with water depth (Biddanda \& Benner 1997). These values are higher than $C R$ rates at Point $\mathrm{C}\left(0.23-1.65 \mu \mathrm{mol} \mathrm{O}_{2} \mathrm{l}^{-1} \mathrm{~d}^{-1}\right)$. CR ranged from 0.07 to $5.8 \mu \mathrm{mol} \mathrm{O} \mathrm{O}^{-1} \mathrm{~d}^{-1}$ in the Bay of Villefranche (Bonilla-Findji et al. 2010) and from 0 to $5.9 \mu \mathrm{mol} \mathrm{O} \mathrm{O}_{2} \mathrm{l}^{-1} \mathrm{~d}^{-1}$ in the epipelagic zone of the DYFAMED site (Lemée et al. 2002). Thus, CR at Point C (300 m) was not systematically different from epipelagic waters in the NW Mediterranean Sea. Overall, these data support the idea that microorganisms in the mesopelagic zone at Point $\mathrm{C}$ are quite active and not much different from the epipelagic layer (see also Gasol et al. 2009).

\section{Prokaryotic community composition in the twilight zone}

In accordance with other sequence data from marine systems, Alpha- and Gammaproteobacteria from Point C (300 m) were the sequences most frequently detected. Deltaproteobacteria sequences were most closely related to sequences from the ALOHA site (Pacific) including samples from the mesopelagic layer (Pham et al. 2008). Also, 2 sequences of Chloroflexi were detected. This group is important in the dark ocean (Morris et al. 2004) and probably specializes in the uptake of L-amino acids, in contrast to the rest of the community that preferentially uses Damino acids (Varela et al. 2008). For Actinobacteria, the closest sequence similarity was detected for samples from the Saanich inlet (British Columbia, Canada) from $200 \mathrm{~m}$ (Walsh et al. 2009), i.e. from waters of the upper mesopelagic zone. Other similarities were often $97 \%$ or less; some of the sequences show little similarity with published sequences $(<90 \%)$, potentially indicating new genera of bacteria.

The closest relatives of archaeal sequences found in databases were detected at $\geq 200 \mathrm{~m}$, and some of the closest relatives were from the Mediterranean Sea (Martín-Cuadrado et al. 2007, Winter et al. 2009a). This suggests a specific archaeal community for the upper dark ocean. All sequences belonged to the Euryarchaeota, which is in accordance with 
DGGE sequence data from the Mediterranean Sea (DYFAMED site; Winter et al. 2009a). The lack of detectable Crenarchaeota was surprising, since fluorescence in situ hybridization analysis shows that Crenarchaeota are more dominant than Euryarchaeota in the dark ocean (including Point C) (Ouverney \& Fuhrman 1999, Karner et al. 2001, Tamburini et al. 2009, Winter et al. 2009a). This could suggest the presence of Euryarchaeota not detected by the primers used. Overall, our data support the idea of specific bacterial and archaeal communities in the mesopelagic zone of the world ocean (for the Mediterranean Sea, see Winter et al. 2009a).

\section{Controlling mechanisms of microbial respiration and diversity}

CR was potentially influenced by seasonal changes as indicated by its inverse relationship with water density (Spearman correlation, PCA-C2), e.g. due to mixing of organic-matter-rich surface water into the mesopelagic zone. PCA suggests that such a relationship could be due to the link between water stratification, TOC, and TEP concentration (PCA-C1/C4). In surface water close to the study area, TOC accumulates during summer, probably due to phosphorus limitation of bacterioplankton production (see Bonilla-Findji et al. 2010 and literature therein). Upon mixing, this TOC could become available to the mesopelagic community and fuel CR. Also, there was a relationship between prokaryotic abundance and TEP abundance (PCA-C3). It is well known that particle-associated prokaryotes are more active than free-living ones (Simon et al. 2002). Thus, a higher percentage of attached prokaryotes due to increased TEP abundance could be the reason for elevated CR. Also, higher prokaryotic activity could increase the production of viruses. In addition, if higher viral abundance corresponds to a higher infection rate, this could stimulate $C R$, since an increasing release of lysis products can stimulate respiration (Motegi et al. 2009). Such a relationship is also indicated by the strong correlation between prokaryotic and viral abundance and CR in the PCA analysis (PCA-C2). Another link could be biomass accumulated during the annual phytoplankton bloom, when water becomes stratified, and the subsequent sinking of particles into the upper mesopelagic zone.

The number of bands detected using genetic fingerprinting by DGGE is an underestimation of the phylotype richness in marine waters. However, the number of DGGE bands can be interpreted as an indicator of phylotype evenness (a crucial diversity parameter describing the distribution of phylotypes in a community), i.e. a low number of bands likely means a lower evenness and a higher dominance of detectable phylotypes (Bonilla-Findji et al. 2009). Thus, the number of DGGE bands can be used in the evaluation of hypotheses on mechanisms controlling diversity parameters such as evenness (Weinbauer et al. 2010). The number of bacterial bands decreased with TOC but increased with TEP concentrations at Point $C$. This suggests that when new organic material is transported into the system, e.g. due to sinking phytoplankton blooms or due to mixing, some bacterial types specifically use this material, thereby reducing dominance. Support for this hypothesis comes from the correlation between water stratification, TOC, TEP concentration, and NBB (PCA-C1). One potential mechanism is by providing niches for prokaryotes on TEP. Particle-associated bacteria can be phylogenetically different from the free-living community (e.g. DeLong et al. 1993), whereas such a trend has not been detected for archaea (Wells et al. 2006). The percentage of attached prokaryotes usually decreases below $50 \mathrm{~m}$ to values less than $10 \%$; however, values up to $29 \%$ have been reported for the upper mesopelagic layer at DYFAMED (Ghiglione et al. 2007). Thus, attached bacteria could have contributed to the observation that the number of bacterial DGGE bands increased with TEP concentration.

An influence of the presence versus absence of viruses on archaeal community composition has been demonstrated (Winter et al. 2004, Malits \& Weinbauer 2009), although it is not clear whether this is due to infection of archaea or due to the control of bacteria, thus indirectly influencing archaea. The relationship of \%V3 with flagellate abundance (Fig. 7) and the number of archaeal bands (Fig. 8) could point to complex interactions between grazing and lysis.

It is also noteworthy that the cluster analysis showed seasonal patterns of bacterial and archaeal community composition. However, these patterns were not identical, suggesting different control mechanisms for these 2 domains of life. Also, correlation and PCA analysis suggested different control mechanisms for the bacterial and the archaeal community composition. Bacterial (and archaeal) community composition was not related to other biological parameters. This indicates that diversity was controlled by mechanisms other than biomass (abundance) or metabolic rates (respiration). 


\section{CONCLUSIONS}

$\mathrm{CR}$, microbial abundances, and community structure showed strong seasonal variability, supporting the emerging observation that the dark pelagic ocean is more dynamic than previously thought (Arístegui et al. 2009, Winter et al. 2009a). Also, our results corroborated evidence that the activity of microorganisms in mesopelagic waters has been underestimated (Reinthaler et al. 2005, Teira et al. 2006, Varela et al. 2008, Gasol et al. 2009). This concurs with a specific bacterial and archaeal community in this water layer. In addition, our study indicates that the bacterial and the archaeal communities are controlled by different mechanisms. Our study also suggests that, besides sinking or organic particles, seasonal mixing could be one of the driving forces of seasonal variability and that an assessment of this variability is essential in order to better understand the role of microbial processes and their relation with microbial diversity in the (upper) mesopelagic realm of the ocean.

Acknowledgements. Data on water temperature and salinity from Point $\mathrm{C}$ were kindly supplied by the SOMLIT coastal observation program. The very constructive comments of 3 anonymous reviewers improved the manuscript. We also appreciate the advice of L. Coppola for the determination of the MLD. This work is a contribution to the 'European Project on Ocean Acidification'(EPOCA) which received funding from the European Community's Seventh Framework Programme (PP7/2007-2013) under grant agreement no. 211384. This study was also supported by projects ANRAQUAPHAGE (no. ANR 07 BDIV 015-06) and ANRMAORY (no. ANR 07 BI.AN 016) from the French Ministry of Science.

\section{LITERATURE CITED}

Agogué H, Brink M, Dinasquet J, Herndl GJ (2008) Major gradients in putatively nitrifying and non-nitrifying Archaea in the deep north Atlantic. Nature 456:788-791

Anderson L, Haraldson C, Roger L (1992) Gran linearization of potentiometric Winkler titration. Mar Chem 37: 179-190

Arístegui J, Agusti S, Middelburg JJ, Duarte CM (2005a) Respiration in the mesopelagic and bathypelagic zones of the oceans. In: del Giorgio PA, Williams PJLeB (eds) Respiration in aquatic ecosystems. Oxford University Press, Oxford, p 181-205

>Arístegui J, Duarte CM, Gasol JM, Alonso-Sáez L (2005b) Active mesopelagic prokaryotes support high respiration in the subtropical northeast Atlantic Ocean. Geophys Res Lett 32:L03608, doi:10.1029/2004GL021863

> Arístegui J, Gasol J, Duarte C, Herndl GJ (2009) Microbial oceanography of the dark ocean's pelagic realm. Limnol Oceanogr 54:1501-1529

Beauvais S, Pedrotti ML, Villa E, Lemée R (2003) Transpar- ent exopolymeric particle (TEP) dynamics in relation to trophic and hydrological conditions in the NW Mediterranean Sea. Mar Ecol Prog Ser 262:97-109

> Benner R, Strom M (1993) A critical evaluation of the analytical blank associated with DOC measurements by hightemperature catalytic oxidation. Mar Chem 41:153-160

Biddanda B, Benner R (1997) Major contribution from mesopelagic plankton to heterotrophic metabolism in the upper ocean. Deep-Sea Res I 44:2069-2085

Bonilla-Findji O (2005) Relationship between bacterial community structure and the functioning of the pelagic ecosystem in the northwestern Mediterranean Sea. PhD thesis, Université Pierre et Marie Curie, Paris

Bonilla-Findji O, Herndl GJ, Gattuso J, Weinbauer MG (2009) Viral and flagellate control of prokaryotic production and community structure in offshore Mediterranean waters. Appl Environ Microbiol 75:4801-4812

Bonilla-Findji O, Gattuso JP, Pizay MD, Weinbauer MG (2010) Autotrophic and heterotrophic metabolism of microbial planktonic communities in an oligotrophic coastal marine ecosystem: seasonal dynamics and episodic events. Biogeosciences 7:3491-3503

$>$ Brussaard CPD (2004) Optimization of procedures for counting viruses by flow cytometry. Appl Environ Microbiol 70:1506-1513

Brussaard CPD, Weinbauer MG, Winter C, Payet J (2010) Quantification of aquatic viruses by flow cytometry. In: Suttle C, Wilhelm SW, Weinbauer MG (eds) Manual of aquatic viral ecology. Association for the Sciences of Limnology and Oceanography, Waco, TX, p 102-109

Burd AB, Hansell DA, Steinberg DK, Anderson TR and others (2010) Assessing the apparent imbalance between geochemical and biochemical indicators of meso-and bathypelagic biological activity: What the @\$\#! is wrong with present calculations of carbon budgets? Deep-Sea Res II 57:1557-1571

Bustillos-Guzmán J, Claustre H, Marty JC (1995) Specific phytoplankton signatures and their relationship to hydrographic conditions in the coastal northwestern Mediterranean Sea. Mar Ecol Prog Ser 124:247-258

- Casamayor EO, Schäfer H, Bañeras L, Pedrós-Alio C, Muyzer G (2000) Identification of and spatio-temporal differences between microbial assemblages from two neighboring sulfurous lakes: comparison by microscopy and denaturing gradient gel electrophoresis. Appl Environ Microbiol 66:499-508

Copin-Montégut C, Bégovic M (2002) Distributions of carbonate properties and oxygen along the water column $(0-2000 \mathrm{~m})$ in the central part of the NW Mediterranean Sea (DYFAMED site): influence of winter vertical mixing on air-sea $\mathrm{CO}_{2}$ and $\mathrm{O}_{2}$ exchanges. Deep-Sea Res II 49: 2049-2066

> DeLong EF, Franks DG, Alldregde AL (1993) Phylogenetic diversity of aggregate-attached vs. free-living marine bacterial assemblages. Limnol Oceanogr 38:924-934

Dickson AG, Sabine CL, Christian JR (2007) Guide to best practices for ocean $\mathrm{CO}_{2}$ measurements. PICES Special Publication 3, IOCCP Rep 8. International Ocean Carbon Coordination Project, Brussels

Fukuda H, Sohrin R, Nagata T, Koike I (2007) Size distribution and biomass of nanoflagellates in meso-and bathypelagic layers of the subarctic Pacific. Aquat Microb Ecol 46:203-207

Gasol JM, del Giorgio PA (2000) Using flow cytometry for counting natural planktonic bacteria and understanding 
the structure of planktonic bacterial communities. Sci Mar 64:197-224

> Gasol JM, Alonso-Sáez L, Vaqué D, Baltar F, Calleja M, Duarte C, Arístegui J (2009) Mesopelagic prokaryotic bulk and single-cell heterotrophic activity and community composition in the NW Africa-Canary Islands coastal-transition zone. Prog Oceanogr 83:189-196

> Ghiglione JF, Mevel G, Puyo-Pay M, Mousseau L, Lebaron $\mathrm{P}$, Goutx M (2007) Diel and seasonal variations in abundance, activity, and community structure of particleattached and free-living bacteria in NW Mediterranean Sea. Microb Ecol 54:217-231

> Hansson L, Agis M, Maier C, Weinbauer MG (2009) Community composition of bacteria associated with coldwater coral Madrepora oculata: within and between colony variability. Mar Ecol Prog Ser 397:89-102

> Herrmann MJ, Somot S (2008) Relevance of ERA40 dynamical downscaling for modeling deep convection in the Mediterranean Sea. Geophys Res Lett 35:L04607, doi: 10.1029/2007GL032442

Kaiser K, Benner R (2012) Organic matter transformations in the upper mesopelagic zone of the North Pacific: chemical composition and linkages to microbial community structure. J Geophys Res 117:C01023, doi:10.1029/2011 JC007141

Karner MB, DeLong EF, Karl DM (2001) Archaeal dominance in the mesopelagic zone of the Pacific Ocean. Nature 409:507-510

Knap AH, Michaels AE, Close A, Ducklow HW, Dickson AG (1996) Protocols for the Joint Global Ocean Flux Study (JGOFS) core measurements. Rep 19. JGOFS, Bergen

Lavigne H, Gattuso JP (2010) Seacarb: Seawater carbonate chemistry with R. R package version 2.3. Available at http: //cran.r-project.org/web/packages/seacarb/index.html

> Lemée R, Rochelle-Newall E, Van Wambeke F, Pizay MD, Rinaldi P, Gattuso JP (2002) Seasonal variation of bacterial production, respiration and growth efficiency in the open NW Mediterranean Sea. Aquat Microb Ecol 29: 227-237

> Liu J, Weinbauer MG, Maier C, Dai M, Gattuso JP (2010) Effect of ocean acidification on microbial diversity and on microbe-driven biogeochemistry and ecosystem functioning. Aquat Microb Ecol 61:291-305

Lukas R, Lindstrom E (1991) The mixed layer of the western equatorial Pacific Ocean. J Geophys Res 96:3343-3357

> Magagnini M, Corinaldesi C, Monticelli LS, Dedomenico E, Danovaro R (2007) Viral abundance and distribution in mesopelagic and bathypelagic waters of the Mediterranean Sea. Deep-Sea Res I 54:1209-1220

Malits A, Weinbauer MG (2009) Effect of turbulence and viruses on prokaryotic cell size, production and diversity. Aquat Microb Ecol 54:243-254

> Mari X (1999) Carbon content and C:N ratio of transparent exopolymeric particles (TEP) produced by bubbling exudates of diatoms. Mar Ecol Prog Ser 183:59-71

> Marsaleix P, Auclair F, Floor JW, Herrmann MJ, Estournel C, Pairaud I, Ulses C (2008) Energy conservation issues in sigma-coordinate free-surface ocean models. Ocean Model 20:61-89

> Martín-Cuadrado AB, López-García P, Alba JC, Moreira D and others (2007) Metagenomics of the deep Mediterranean, a warm bathypelagic habitat. PLoS ONE 2:e914

> Marty JC, Chiavérini J, Pizay MD, Avril B (2002) Seasonal and interannual dynamics of nutrients and phytoplankton pigments in the western Mediterranean Sea at the
DYFAMED time-series station (1991-1999). Deep-Sea Res II 49:1965-1985

Middelboe M, Jørgensen NOG, Kroer N (1996) Effects of viruses on nutrient turnover and growth efficiency of noninfected marine bacterioplankton. Appl Environ Microbiol 62:1991-1997

> Morris RM, Rappe MS, Urbach E, Connon SA, Giovannoni SJ (2004) Prevalence of the Chloroflexi-related SAR202 bacterioplankton cluster throughout the mesopelagic zone and deep ocean. Appl Environ Microbiol 70:2836-2842

Motegi C, Nagata T, Miki T, Weinbauer MG, Legendre L, Rassoulzadegan F (2009) Viral control of bacterial growth efficiency in marine pelagic environments. Limnol Oceanogr 54:1901-1910

> Ouverney CC, Fuhrman JA (1999) Combined microautoradiography-16s rRNA probe technique for determination of radioisotope uptake by specific microbial cell types in situ. Appl Environ Microbiol 65:1746-1752

> Parada V, Sintes E, Van Aken HM, Weinbauer MG, Herndl GJ (2007) Viral abundance, decay and diversity in the meso- and bathypelagic waters of the north Atlantic. Appl Environ Microbiol 73:4429-4438

> Pham VD, Konstantinidis KT, Palden T, DeLong EF (2008) Phylogenetic analyses of ribosomal DNA-containing bacterioplankton genome fragments from a $4000 \mathrm{~m}$ vertical profile in the north Pacific subtropical gyre. Environ Microbiol 10:2313-2330

> Reinthaler T, Winter C, Herndl GJ (2005) Relationship between bacterioplankton richness, respiration, and production in the southern North Sea. Appl Environ Microbiol 71:2260-2266

Reinthaler T, Van Aken H, Veth C, Arístegui J, Robinson C, Williams P (2006) Prokaryotic respiration and production in the meso-and bathypelagic realm of the eastern and western north Atlantic basin. Limnol Oceanogr 51: 1262-1273

Robinson C, Steinberg DK, Anderson TR, Arístegui J and others (2010) Mesopelagic zone ecology and biogeochemistry - a synthesis. Deep-Sea Res II 57:1504-1518

Sánchez O, Gasol JM, Massana R, Mas J, Pedros-Alio C (2007) Comparison of different denaturing gradient gel electrophoresis primer sets for the study of marine bacterioplankton communities. Appl Environ Microbiol 73: 5962-5967

Schäfer H, Muyzer G (2001) Denaturing gradient gel electrophoresis in marine microbial ecology. In: Paul JH (ed) Methods in microbiology, Vol 30: Marine microbiology. Academic Press, London, p 425-468

Sherr EB, Caron DA, Sherr BF (1993) Staining of heterotrophic protists for visualization via epifluorescence microscopy. In: Kemp PF, Sherr BF, Sherr EB, Cole JJ (eds) Handbook of methods in aquatic microbial ecology. Lewis Publishers, Boca Raton, FL, p 895-701

Simon M, Grossart HP, Schweitzer B, Ploug H (2002) Microbial ecology of organic aggregates in aquatic ecosystems. Aquat Microb Ecol 28:175-211

Strickland JDH, Parsons TR (1972) A practical handbook of seawater analysis. Bull 167. Fisheries Research Board of Canada, Ottawa, ON

Swan BK, Martinez-Garcia M, Preston CM, Sczyrba A and others (2011) Potential for chemolithoautotrophy among ubiquitous bacteria lineages in the dark ocean. Science 333:1296-1300

Tamburini C, Garel M, Al Ali B, Mérigot B, Kriwy P, Charriè Budillon G (2009) Distribution and activity of Bacteria 
and Archaea in the different water masses of the Tyrrhenian Sea. Deep-Sea Res II 56:700-712

Tanaka T, Rassoulzadegan F (2002) Full-depth profile $(0-2000 \mathrm{~m})$ of bacteria, heterotrophic nanoflagellates and ciliates in the NW Mediterranean Sea: vertical partitioning of microbial trophic structure. Deep-Sea Res II 49:2093-2107

Teira E, Lebaron P, Van Aken H, Herndl GJ (2006) Distribution and activity of Bacteria and Archaea in the deep water masses of the North Atlantic. Limnol Oceanogr 51: 2131-2144

Turley C, Stutt E (2000) Depth-related cell-specific bacterial leucine incorporation rates on particles and its biogeochemical significance in the northwest Mediterranean. Limnol Oceanogr 45:419-425

Vandromme P, Stemmann L, Berline L, Gasparini S and others (2011) Inter-annual fluctuations of zooplankton communities in the Bay of Villefranche-sur-mer from 1995 to 2005 (northern Ligurian Sea, France). Biogeosciences 8: 3143-3158

Varela MM, Van Aken HM, Herndl GJ (2008) Abundance and activity of Chloroflexi-type sar202 bacterioplankton in the meso- and bathypelagic waters of the (sub)tropical Atlantic. Environ Microbiol 10:1903-1911

Walsh DA, Zaikova E, Howes CG, Song YC and others (2009) Metagenome of a versatile chemolithoautotroph from expanding oceanic dead zones. Science 326: 578-582

Weinbauer MG, Kerros ME, Motegi C, Wilhartitz IC, Rassoulzadegan F, Torréton JP, Mari X (2010) Bacterial com- munity composition and potential controlling mechanisms along a trophic gradient in a barrier reef system. Aquat Microb Ecol 60:15-28

Weinbauer MG, Mari X, Gattuso JP (2011) Effect of ocean acidification on the diversity and activity of heterotrophic marine microorganisms. In: Gattuso JP, Hansson L (eds) Ocean acidification. Oxford University Press, Oxford, p 83-98

Wells LE, Cordray M, Bowerman S, Miller LA, Vincent WF, Deming JW (2006) Archaea in particle-rich waters of the Beaufort Shelf and Franklin Bay, Canadian Arctic: clues to an allochthonous origin? Limnol Oceanogr 51:47-59

Winter C, Weinbauer MG (2010) Randomly amplified polymorphic DNA reveals tight links between viruses and microbes in the bathypelagic zone of the northwestern Mediterranean Sea. Appl Environ Microbiol 76:6724-6732

Winter C, Smit A, Herndl GJ, Weinbauer MG (2004) Impact of virioplankton on archaeal and bacterial community richness in seawater batch cultures. Appl Environ Microbiol 70:804-813

> Winter C, Kerros ME, Weinbauer MG (2009a) Seasonal changes of bacterial and archaeal communities in the dark ocean: evidence from the Mediterranean Sea. Limnol Oceanogr 54:160-170

> Winter C, Kerros ME, Weinbauer MG (2009b) Seasonal and depth-related dynamics of prokaryotes and viruses in surface and deep waters of the northwestern Mediterranean Sea. Deep-Sea Res I 56:1972-1982

\section{Appendix 1}

Table A1. Seasonal variability of bacterial community composition at Point C in the NW Mediterranean Sea. Schematic representation of the denaturing gradient gel electrophoresis banding patterns obtained for each sampling. Presence and absence of bands is indicated by black and white squares, respectively. Correspondence between band number and ID of sequenced bands (see Table A2): Band $1=\mathrm{B} 01,2=\mathrm{B} 02,3=\mathrm{B} 03,4=\mathrm{B} 04,5=\mathrm{B} 05,6=\mathrm{B} 06,9=\mathrm{B} 12,10=\mathrm{B} 13,15=\mathrm{B} 20,16=\mathrm{B} 16,18=\mathrm{B} 22$, $19=\mathrm{B} 17,20=\mathrm{B} 18,21=\mathrm{B} 19,22=\mathrm{B} 31,23=\mathrm{B} 23,24=\mathrm{B} 24,25=\mathrm{B} 25,26=\mathrm{B} 29,27=\mathrm{B} 30$

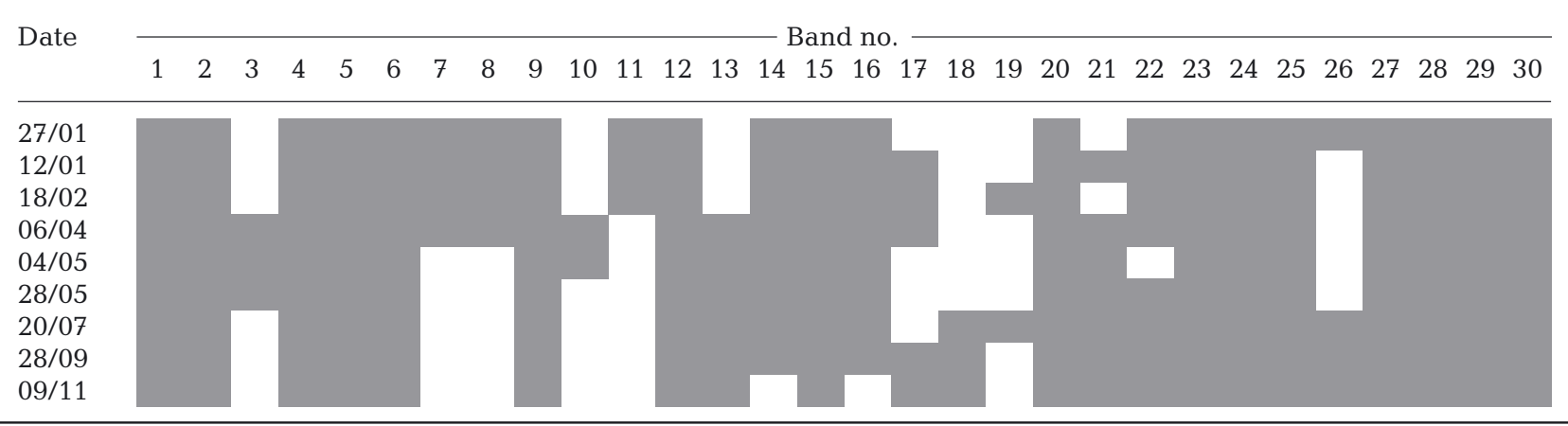


Table A2. Phylogenetic affiliation of bacterial sequences from denaturing gradient gel electrophoresis bands with closest uncultured and cultured matches. The number of bases used to calculate sequence similarity (\%) is given in parentheses in the third column

\begin{tabular}{|llll}
\hline Band ID & Closest match & Sequence similarity & Taxonomic group \\
\hline B01 & Alphaproteobacterium SCGC AAA298-O14 & $94(527)$ & Alphaproteobacteria \\
B02 & Alphaproteobacterium SCGC AAA298-I19 & $94(506)$ & Alphaproteobacteria \\
B03 & Alphaproteobacterium SCGC AAA298-J15 & $99(520)$ & Alphaproteobacteria \\
B04 & Alphaproteobacterium SCGC AAA298-J15 & $96(503)$ & Alphaproteobacteria \\
B05 & Alphaproteobacterium SCGC AAA298-I19 & $89(505)$ & Alphaproteobacteria \\
B06 & Uncultured bacterium DYFBac12 16S & $73(518)$ & Not identified \\
B11 & Gammaproteobacterium, 3833-27F & $74(501)$ & Gammaproteobacteria \\
B12 & Gammaproteobacterium clone SHZW474 & $95(547)$ & Gammaproteobacteria \\
B13 & Actinobacterium SHAS654 16S & $98(507)$ & Actinobacteria \\
B14 & Gammaproteobacterium SCGC AAA015-P14 & $84(520)$ & Gammaproteobacteria \\
B16 & Alphaproteobacterium LNA_100608-9 & $90(500)$ & Alphaproteobacteria \\
B17 & Porphyrobacter sp. Bo53-33 & $83(524)$ & Alphaproteobacteria \\
B18 & Vibrio sp. BSw21772 16S & $93(524)$ & Gammaproteobacteria \\
B19 & Alcanivorax sp. S15-9 16S & $78(520)$ & Gammaproteobacteria \\
B20 & Gammaproteobacterium LS7 16S & $74(437)$ & Gammaproteobacteria \\
B22 & Uncultured bacterium d1-57 & $84(428)$ & Not identified \\
B23 & Deltaproteobacterium SCGC AAA240-N18 & $97(505)$ & Deltaproteobacteria \\
B24 & Chloroflexi bacterium SCGC AAA240-O15 & $97(502)$ & Chloroflexi \\
B25 & Chloroflexi bacterium KS-C23 & $83(499)$ & Chloroflexi \\
B29 & Uncultured bacterium DYFBac9 & $75(520)$ & Not identified \\
B30 & SAR324 cluster bacterium HF200_27L11 & $97(503)$ & Deltaproteobacteria \\
B31 & Uncultured bacterium, D1B8 & $80(504)$ & Not identified \\
& & & \\
\hline
\end{tabular}

Table A3. Seasonal variability of archaeal community composition at Point C in the NW Mediterranean Sea. Schematic representation of the denaturing gradient gel electrophoresis banding patterns obtained for each sampling. Presence and absence of bands is indicated by black and white squares, respectively. Correspondence between band number and ID of sequenced bands (see Table A4): Band $2=$ $\mathrm{A} 32,3=\mathrm{A} 34,5=\mathrm{A} 35,6=\mathrm{A} 38,7=\mathrm{A} 44,8=\mathrm{A} 36,10=\mathrm{A} 41$,

$$
11=\mathrm{A} 42,12=\mathrm{A} 43
$$

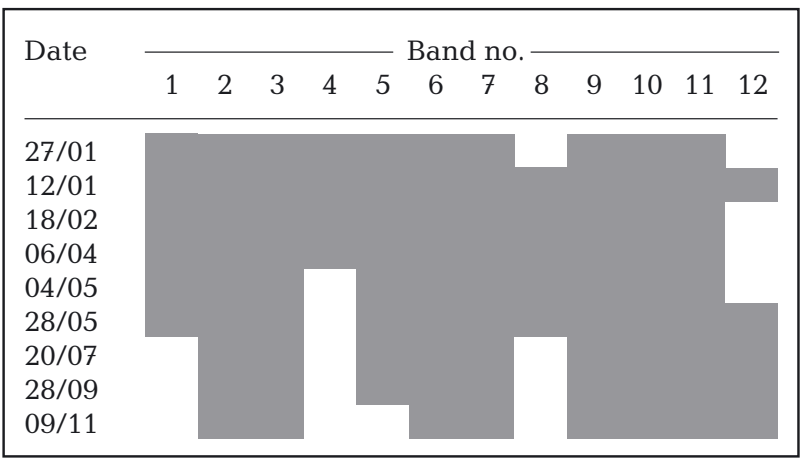

Editorial responsibility: Gerhard Herndl, Vienna, Austria
Table A4. Phylogenetic affiliation of archaeal sequences from denaturing gradient gel electrophoresis (DGGE) bands with closest uncultured and cultured matches. The number of bases used to calculate sequence similarity (\%) is given in parentheses in the third column. All archaeal bands that could be successfully sequenced belonged to Euryarchaeota

\begin{tabular}{|c|c|c|}
\hline $\begin{array}{l}\text { Band } \\
\text { ID }\end{array}$ & Closest match & $\begin{array}{l}\text { Sequence } \\
\text { similarity }\end{array}$ \\
\hline A32 & $\begin{array}{l}\text { Marine group II euryarchaeote } \\
\text { HF500_11G07 16S }\end{array}$ & $98(510)$ \\
\hline A34 & Euryarchaeote SCICEX122402B1 & $98(511)$ \\
\hline A35 & $\begin{array}{l}\text { Uncultured euryarchaeote, } \\
\text { TKTMmvp-A25 }\end{array}$ & $92(520)$ \\
\hline A36 & Euryarchaeote KM3-72-G2 & 97 (511) \\
\hline A38 & $\begin{array}{l}\text { Marine group II euryarchaeote } \\
\text { HF500_24F01 16S }\end{array}$ & $94(512)$ \\
\hline A44 & Euryarchaeote clone SCICEX122429E4 1 & $95(511)$ \\
\hline A41 & Euryarchaeote clone KM3-72-G2 1 & $99(511)$ \\
\hline A42 & $\begin{array}{l}\text { Marine group II euryarchaeote } \\
\text { HF200_84A01 }\end{array}$ & $98(487)$ \\
\hline A43 & Euryarchaeote clone KM3-85-F5 & $85(543)$ \\
\hline
\end{tabular}

Submitted: February 18, 2013; Accepted: September 24, 2013 Proofs received from author(s): December 10, 2013 